\title{
Re-visiting protein-centric two-tier classification of existing DNA-protein complexes
}

\author{
Sony Malhotra and Ramanathan Sowdhamini*
}

\begin{abstract}
Background: Precise DNA-protein interactions play most important and vital role in maintaining the normal physiological functioning of the cell, as it controls many high fidelity cellular processes. Detailed study of the nature of these interactions has paved the way for understanding the mechanisms behind the biological processes in which they are involved. Earlier in 2000, a systematic classification of DNA-protein complexes based on the structural analysis of the proteins was proposed at two tiers, namely groups and families. With the advancement in the number and resolution of structures of DNA-protein complexes deposited in the Protein Data Bank, it is important to revisit the existing classification.

Results: On the basis of the sequence analysis of DNA binding proteins, we have built upon the protein centric, two-tier classification of DNA-protein complexes by adding new members to existing families and making new families and groups. While classifying the new complexes, we also realised the emergence of new groups and families. The new group observed was where $\beta$-propeller was seen to interact with DNA. There were 34 SCOP folds which were observed to be present in the complexes of both old and new classifications, whereas 28 folds are present exclusively in the new complexes. Some new families noticed were NarL transcription factor, Z-a DNA binding proteins, Forkhead transcription factor, AP2 protein, Methyl CpG binding protein etc.

Conclusions: Our results suggest that with the increasing number of availability of DNA-protein complexes in Protein Data Bank, the number of families in the classification increased by approximately three fold. The folds present exclusively in newly classified complexes is suggestive of inclusion of proteins with new function in new classification, the most populated of which are the folds responsible for DNA damage repair. The proposed revisited classification can be used to perform genome-wide surveys in the genomes of interest for the presence of DNA-binding proteins. Further analysis of these complexes can aid in developing algorithms for identifying DNA-binding proteins and their family members from mere sequence information.
\end{abstract}

Keywords: DNA, Classification, DNA-protein interactions, Genome-wide survey, Sequence searches

\section{Background}

The driving forces for the cell to survive and regulate its various processes are the specific interactions between macromolecules. Protein-nucleic acid interactions are important for many high fidelity cellular processes. Both of these macromolecules are known to be involved in various important mechanisms and processes of systems biology- replication, transcription, translation, recombination, DNA-repair, DNA packaging etc. Therefore, DNA-binding proteins serve as the key players in maintaining cell viability and proliferation.

\footnotetext{
* Correspondence: mini@ncbs.res.in

National Centre for Biological Sciences (TIFR), UAS-GKVK Campus, Bellary Road, Bangalore 560 065, India
}

Also, DNA-binding proteins constitute both eukaryotic and prokaryotic proteomes. The interplay between DNA and proteins is most fundamental interaction in biology and also has implications in the field of medicine, pharmacology and biotechnology. The diverse function of DNA-binding proteins is accompanied by the diversity in their sequences and structures.

Therefore, to elucidate and understand the mechanism of any of the biological processes involving DNAbinding proteins, it is necessary and useful to study the nature of these nucleic acid-protein complexes formed in order to accomplish the specific function [1]. There have been many earlier attempts to study the nature of

\section{Biomed Central}

(C) 2012 Malhotra and Sowdhamini; licensee BioMed Central Ltd. This is an Open Access article distributed under the terms of the Creative Commons Attribution License (http://creativecommons.org/licenses/by/2.0), which permits unrestricted use, distribution, and reproduction in any medium, provided the original work is properly cited. 
contacts between DNA and protein, example, H-bond $[2,3]$, and water mediated interactions [4].

In the past, apart from the concern in understanding the interactions between the two macromolecules, interest had also been focused on classifying DNA-protein complexes. The classification based on the structures of DNA-binding domains was first proposed by Harrison in 1991 [5]. Luscombe and coworkers (2000) classified the DNA-protein complexes into 8 groups and 54 families using the structures of DNA binding domain of the protein and on the basis of similarities of overall protein folds, the complexes were classified into different groups. In this existing classification, each group of proteins exhibit similar DNA binding mode, but proteins in some groups differ in terms of structure, mode of interaction and wide range of recognition sequence [1]. Subsequently, in 2002, there was a classification which was based on the analysis of the structural domains interacting with DNA and then clustering these domains was based on structural similarity [6]. Later, in 2006, there was an attempt towards classifying DNA-protein complexes, using descriptors characterizing DNA-protein interactions like number of atomic contacts at major and minor groove, buried surface area at the interface etc. [7].

All the approaches of classification, mentioned above, were protein-centric in nature which implies that the classification was based on the features of the protein partner of the complex. However, in 2006, completely new viewpoint of classification was proposed by Sen et al. which was DNA-centric in nature and hence based on the features of nucleic acid part of the complex. They made an attempt to classify these complexes based on a clustering approach that incorporates most of the key structural parameters involved in recognition process [8].

In the present study, we have made an attempt towards protein-centric classification of DNA-protein complexes. To study the nature of these complexes, it is important to understand the structure of the DNAbinding domains present in proteins, namely from the Protein Structure Data Bank (PDB) [9]. With the advancement in number and the resolution of structures of DNA-protein complexes, it became important to revisit the existing classification. The classification we propose is based more on sequence similarity rather than structural alignments. Sequence-based approaches towards understanding DNA-binding proteins will gear the developed classification scheme and search algorithms to search effectively in whole genomes, where mere sequence information is available. Re-examining the existing classification will play an important role in understanding this important class of proteins known to form complexes with DNA.

Firstly, PDB was queried for dsDNA-protein complexes (see Methods) with resolution better than $3 \AA$.
We have built upon the existing groups and families of DNA binding proteins in classification proposed by Luscombe et al., 2000 and selected representatives of each of the families which were also validated using Jack-knifing (leave-one-out) approach. For each of the representatives selected for different families, PSIBLAST [10] profiles were built using Jump Start PSIBLAST. The new complexes were individually used as a query against the database of representatives' profiles using RPS-BLAST [11]. This helped to populate the existing families. The left-out new complexes were clustered and classified based on their biological function and grouped according to the presence of the DNA binding motif in the protein partner. As a result, we were able to classify DNA binding proteins in to 174 families and nine groups.

This newly built two-tier classification where the group indicates the type of DNA binding motif present in the protein partner (except in the Enzyme group where group name indicates that the protein possesses catalytic activity upon binding to DNA) and the family level corresponds to the functional role of the protein, can further be used for performing genome-wide surveys in organism(s) of interest for the presence of DNA-binding proteins.

\section{Methods}

\section{Selection of DNA-protein complexes from PDB}

$\mathrm{PDB}$ was searched for DNA-protein complexes having resolution better than $3 \AA$. The complexes were further filtered for having only double-stranded DNA (dsDNA) and all single-stranded DNA (ssDNA), quadruple DNA (it is higher order structure of nucleic acids which is Grich and forms four-stranded structure), nucleosomal and previously classified complexes were removed.

\section{Representatives' selection for existing $\mathbf{5 4}$ families}

For all the 54 families from Thornton's group 2000 classification, representatives were selected and validated. First the pairwise percentage identities were obtained between members of a family using ClustalX [12]. The families having wide percentage identity distribution were carefully analyzed for their representative selection in terms of coverage of each family member as described below. The statistical approach Jack-knifing (leave-oneout approach) was used to validate the selection of representatives in terms of its coverage for being able to pick up all of its own family members. Best representative was selected by providing equal chance to every family member to become the representative and then observing its performance as measured by coverage over its own family (other members of its family are able to pick the representative(s) profile). Either a single member or a combination of members is chosen so as to obtain $100 \%$ coverage for a particular family. 
In families, where one member was not able to have $100 \%$ coverage over its family, more than one member was selected as representatives. For all the selected representatives, PSI-BLAST profiles were built using Jump-start PSI-BLAST at stringent Evalue of $10^{-10}$, for 20 iterations, where alignment of all family members including the representative was also given as input for profile creation.

Also, the representatives that were selected were tested for their performance by making their PSI-BLAST profiles against dummy database (a database having completely unrelated sequences which are non-DNA binding in nature), so as to ensure that the representative profile is powerful and it is not biased by other sequences, included during profile creation, in its coverage. Therefore, a dummy database helped us to make sure that there were no additional members that might drift the direction of sequence searches. If the selected best representative(s) profile built against this dummy database was still observed to have $100 \%$ coverage on its family, it was selected as a true representative.

\section{Classification of new complexes}

The previously existing families were first populated with new complexes with the help of RPS-BLAST, where all profiles of representatives were assembled into a database and the complexes individually were allowed to pick a profile from this database using RPS-BLAST at an E-value of $10^{-3}$. The single-profile pickers were easily added to the respective family whereas the multiple- or no- profile pickers were dealt with separately.

Multiple-profile pickers which were observed to be ternary complexes were split into chains and added to the respective families. No-profile pickers were clustered using all-against-all BLAST approach and were added in to new groups and families based on the DNA binding motif and their biological function respectively. Figure 1 depicts the schematic of the overall methodology adopted to classify the new protein-DNA complexes into groups and families.

\section{New families and their representatives}

After the new classification was laid down, for each of the newly formed families and the old families which have undergone expansion in terms of addition of members, new representatives were selected adopting the same approach as mentioned above.

The best representative of newly formed families was selected using Jack-knifing and phylogeny. The decision to choose either of the one techniques was based on the size of the family and also the distribution of the percent identity plot within the family (Figure 2 depicts the methodology of selecting the representatives). For twomember families, both the members are allowed to behave as a representative and then both are assessed in terms of their coverage for that particular family. If the old representative is able to have $100 \%$ coverage on the family, then it was retained as a new representative also.

In the case of multi-member families, the pairwise percentage identity distribution was observed first and in the case of a narrow distribution, any one of the member is assessed for its coverage (as narrow distribution implies the members are nearly identical). Wide percent identity distribution requires decision making for the number of members in a given family. As Jack-knifing is computationally intensive technique $[\mathrm{N}(\mathrm{N}-1)$ profiles creation for $\mathrm{N}$ members], families having $<50$ members were subjected to Jack-knifing but if the members in family are $>50$, first clustering was performed and representative "seeds" from cluster(s) were chosen and individually as well as in combination from different clusters, were assessed for their coverage.

\section{Results and discussion \\ Dataset of DNA-protein complex structures}

Structures of DNA-protein complexes solved using X-Ray crystallography and resolution better than $3 \AA$ were obtained from PDB. From this dataset, the protein DNA complexes having ssDNA or quadruple DNA was excluded from this classification (see Methods). Some of the complexes were ternary ones having two proteins and DNA molecule; these were split into individual chains and then considered for classification. Thornton and coworkers classified 230 complexes in 2000 and now approximately a four-fold increase in the number of complexes which needs classification was observed (1009 complexes).

As of February 2010, 1354 protein DNA complexes were retrieved from PDB. Already classified complexes (241 (including ternary complexes), [1]), ssDNA, quadruple DNA complexes, ribonucleases, ATP-bound complexes and tri/octa peptides bound to nucleic acid were also removed. This resulted in a dataset of 1009 DNAprotein complexes which need to be classified.

Further, it was observed that there were approximately equal number of prokaryotic and eukaryotic complexes ( $44 \%$ each) but only a very small percent $11 \%$ complexes were from viruses (Figure 3). 


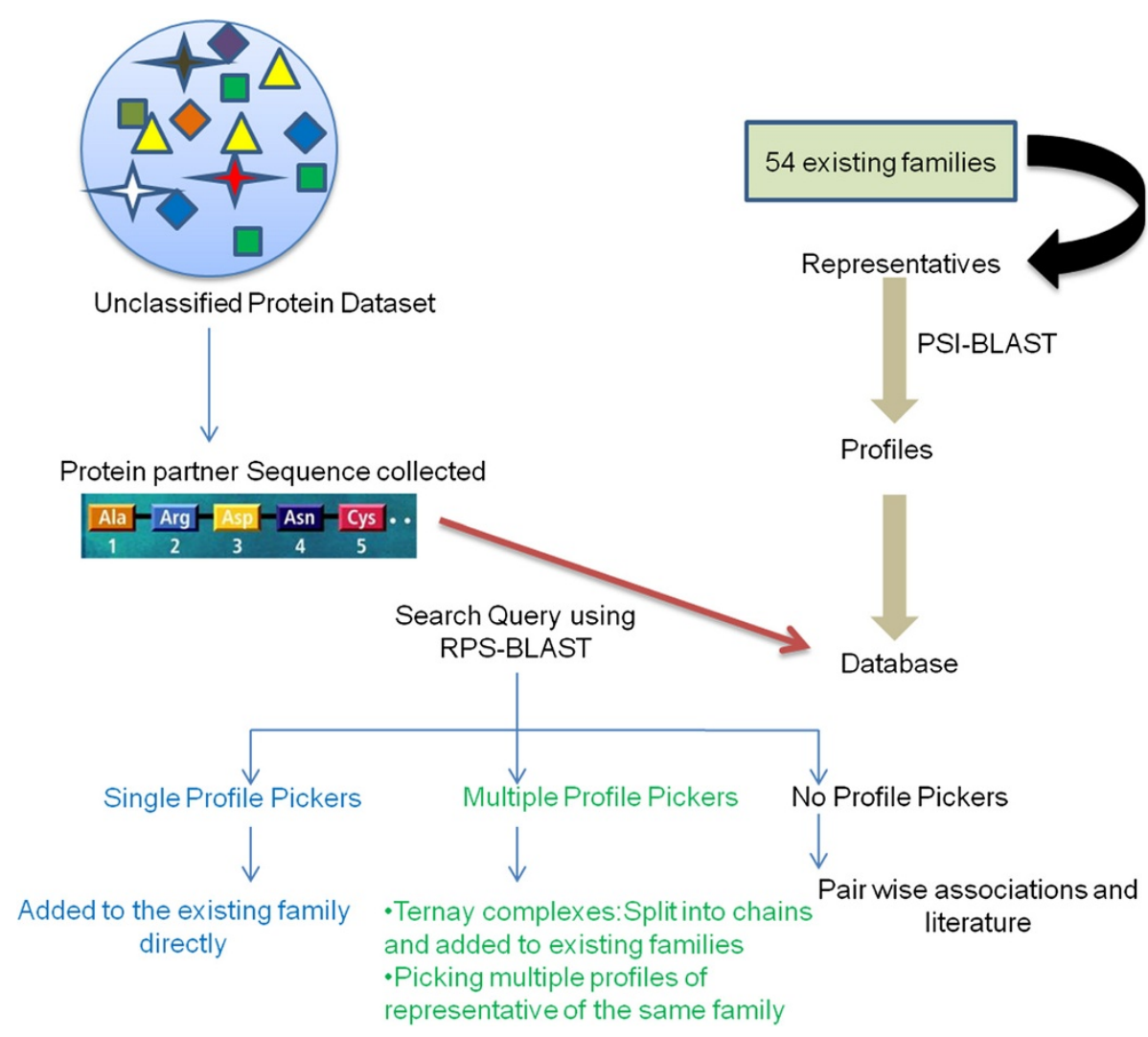

Figure 1 Methodology. Schematic of the overall methodology for classifying new complexes using approaches like PSI-BLAST and RPS-BLAST.

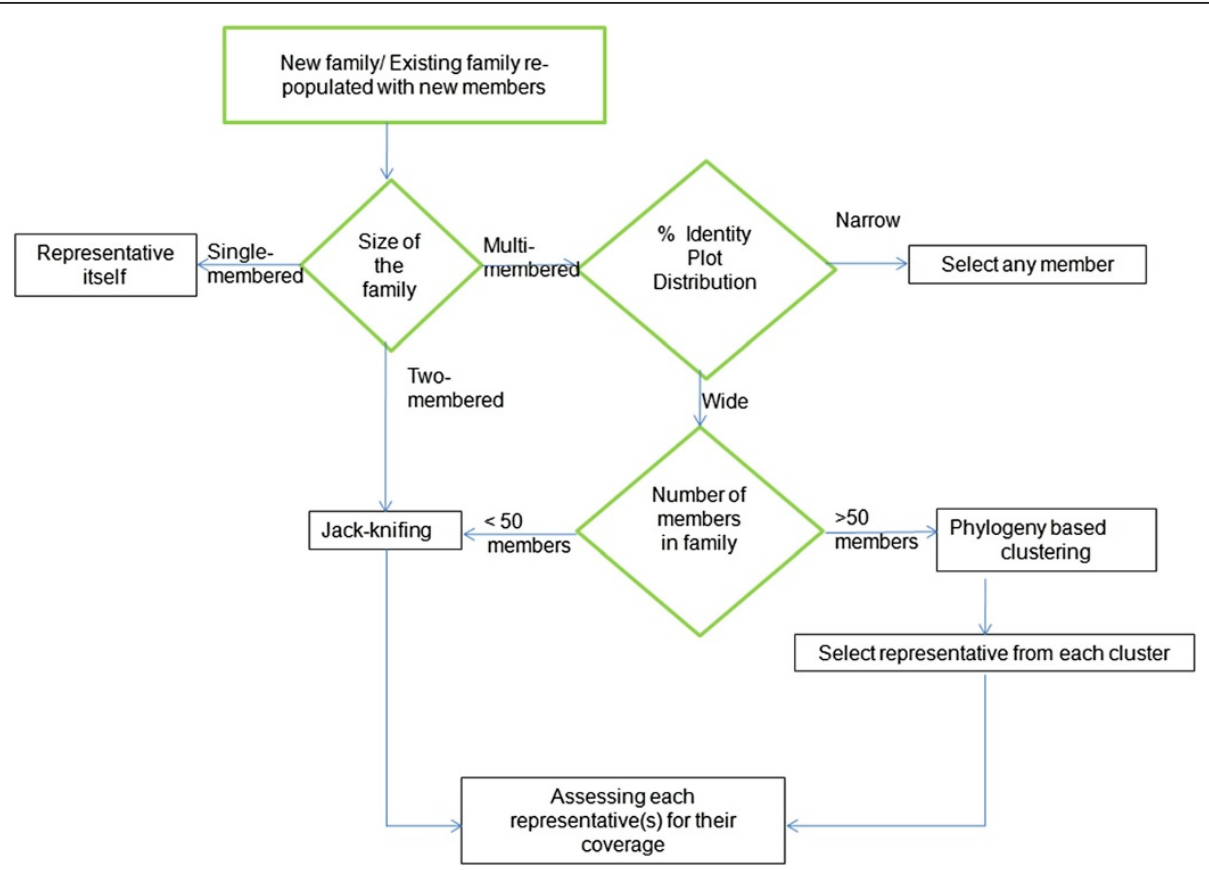

Figure 2 Representative Selection. Schematic of the methodology for selecting reprsentatives of new families formed after classification. If the percentage identity plot is narrow, any member of the family is assessed for its coverage, but if the distribution of percent identity is wide, the decision of whether to perform Jack-knifing is dependent on the size of the family. 


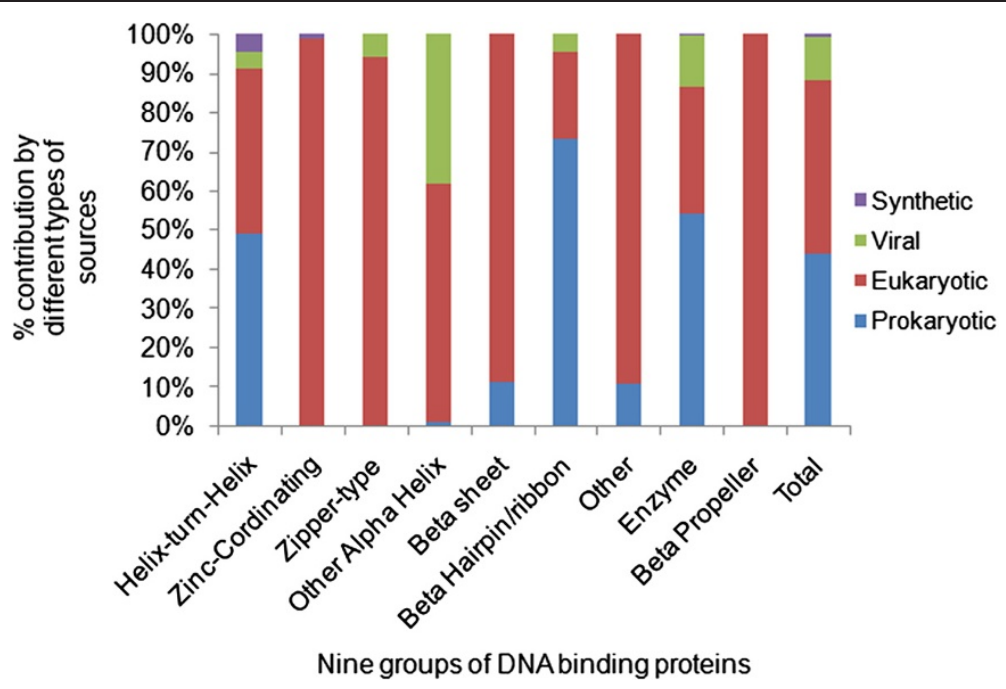

Figure 3 Source of new nucleic acid-protein complexes. Source of the classified DNA-protein complexes (including previously classified complexes). Prokaryotic and eukaryotic complexes were almost equal in percentages (44\%) and small $11 \%$ of the total complexes were viral DNA-protein complexes.

\section{Representatives of DNA-binding protein families}

For all the existing 54 families in Thornton's classification [1], best representative was selected with the help of Jack-knifing approach. For these 54 families, 59 representatives were selected ensuring 100\% coverage.

For 23 out of 54 Thornton's families, which were multi-membered families ( $>2$ members), pairwise percentage identities were obtained using ClustalX. Figure 4 displays the percent identity distribution for these families in form of Box and whisker plot. For 10 families, a narrow percentage identity range was observed and in these families any one member was assessed for its coverage. In all such cases, one member was observed to have $100 \%$ coverage for family. But for families having wide percentage identity range (13 families), each member was given a chance to behave as a representative and later they were assessed for coverage over their family. The total number of representatives selected for 54 families were 59 (Table 1), implying there was more than one representative for some families. These families were Homing endonuclease (2), Homeodomain (3), DNA Polymerase T7 (2) and Transcription factor (2).

For all the 59 selected representatives, PSI-BLAST profiles were again built against dummy database using the earlier profile creation parameters (as described in Methods). The sequences included in the dummy

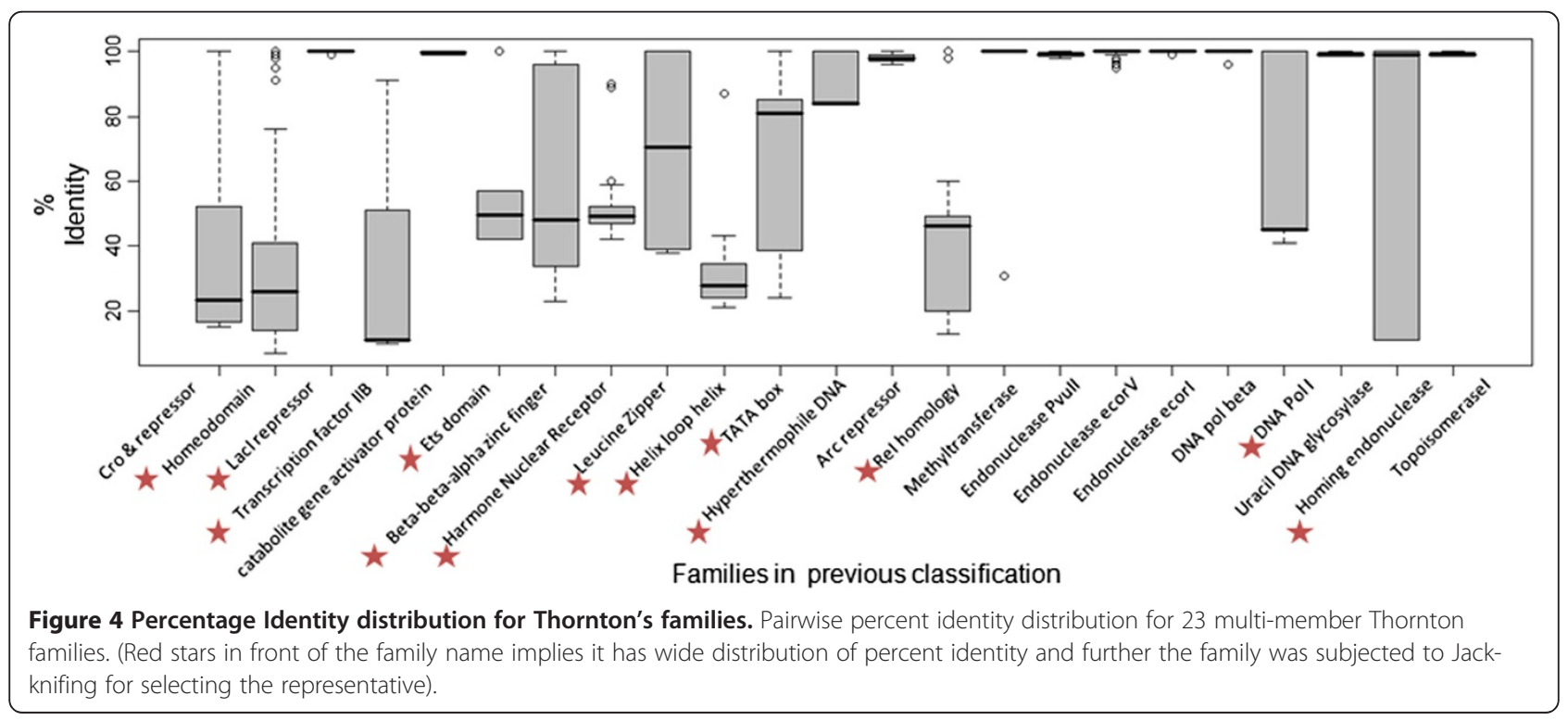


Table 1 Representatives for previous families 54 existing families (Thornton classification) representatives were selected and were validated using Jack-knifing

\begin{tabular}{lll}
\hline \multicolumn{1}{c}{ Group } & \multicolumn{1}{c}{ Families } & Representative(s) \\
\hline HTH & Cro \& repressor & 1LMB \\
& Homeodomain & 1FJL, 1HDD, 6PAX \\
& Lacl repressor & $1 \mathrm{WET}$ \\
& Endonuclease Fok1 & 1FOK \\
& Gamma Delta resolvase & $1 \mathrm{GDT}$ \\
& Hin recombinase & $1 \mathrm{HCR}$ \\
& RAP1 family & $11 \mathrm{GN}$ \\
& Prd paired domain & $1 \mathrm{PDN}$ \\
& Tc3 transposase & $1 \mathrm{TC} 3$ \\
& Trp repressor & $1 \mathrm{TRR}$ \\
& Diptheria tox repressor & $1 \mathrm{DDN}$ \\
& Transcription factor IIB & $1 \mathrm{D} 3 \mathrm{U}$ \\
Interferon regulatory & $2 \mathrm{RFF}$ \\
Catabolite gene activator protein & $1 \mathrm{RUO}$ \\
Transcription factor & $1 \mathrm{CF} 7,3 \mathrm{HTS}$ \\
Ets domain & $1 \mathrm{BC} 8$ \\
\hline
\end{tabular}

Zinc Co-ordinating

$\begin{array}{ll}\beta \text { - } \beta \text {-a zinc finger } & \text { 1ZAA } \\ \text { Harmone Nuclear Receptor } & \text { 2NLL } \\ \text { Loop sheet helix } & \text { 1TSR } \\ \text { GAL4 type } & \text { 1ZME }\end{array}$

\begin{tabular}{|c|c|c|}
\hline \multicolumn{3}{|l|}{ Zipper type } \\
\hline & Leucine Zipper & 1YSA \\
\hline & Helix loop helix & 1AN2 \\
\hline \multicolumn{3}{|c|}{ Other-a Helix } \\
\hline & Pappilomavirus 1 E2 & $2 \mathrm{BOP}$ \\
\hline & Histone & $1 \mathrm{AOI}$ \\
\hline & EBNA1 nuclear protein & 1B3T \\
\hline & Skn-1 transcription factor & $1 \mathrm{SKN}$ \\
\hline & Cre Recombinase & $1 C R X$ \\
\hline & High Mobility Group & 1QRV \\
\hline & MADS box & $1 \mathrm{MNM}$ \\
\hline \multicolumn{3}{|l|}{$\beta$-Sheet } \\
\hline & TATA box binding & 1YTB \\
\hline \multicolumn{3}{|c|}{$\beta$-Hairpin/Ribbon } \\
\hline & MetJ repressor & $1 C M A$ \\
\hline & Tus replication terminator & $1 \mathrm{ECR}$ \\
\hline & Integration host factor & $11 \mathrm{HF}$ \\
\hline & Transcription Factor T-domain & $1 \mathrm{XBR}$ \\
\hline & Hyperthermophile DNA & $1 \mathrm{AZP}$ \\
\hline & Arc repressor & IPAR \\
\hline
\end{tabular}

Table 1 Representatives for previous families 54 existing families (Thornton classification) representatives were selected and were validated using Jack-knifing (Continued)

\begin{tabular}{|c|c|c|}
\hline \multicolumn{3}{|l|}{ Other } \\
\hline & Rel homology & 1SVC \\
\hline & Stat protein & 1BF5 \\
\hline \multicolumn{3}{|c|}{ Enzyme } \\
\hline & Methyltransferase & $6 \mathrm{MHT}$ \\
\hline & Endonuclease Pvull & $3 \mathrm{PVI}$ \\
\hline & Endonuclease ecorV & IRVA \\
\hline & Endonuclease ecorl & 1QPS \\
\hline & Endonuclease BamHI & 3BAM \\
\hline & Enonuclease V & IVAS \\
\hline & Dnase I & 2DNJ \\
\hline & DNA mismatch endonuclease & $1 \mathrm{CWO}$ \\
\hline & DNA polymerase $\beta$ & 1BPY \\
\hline & DNA Polymerase I & 2BDP \\
\hline & DNA Polymerase T7 & $1 \mathrm{TTP}, 1 \mathrm{CLQ}$ \\
\hline & HIV Reverse Transcriptase & $2 \mathrm{HMl}$ \\
\hline & Uracil DNA glycosylase & $1 S S P$ \\
\hline & \multicolumn{2}{|c|}{ 3-Methyladenine DNA glycosylase 1BNK } \\
\hline & Homing endonuclease & 1A73, 1BP7 \\
\hline & Topoisomerasel & 1A31 \\
\hline
\end{tabular}

database were foetal deoxyhemoglobin, relaxin, subtilisin, chymotrypsin and human deoxyhemoglobin. The 59 new profiles built using dummy database were again assessed for their coverage and all were still observed to be best representatives.

\section{Classification of new complexes}

After performing the RPS-BLAST search for each of the 1009 new complexes against database of the family representatives, $444(\sim 44 \%)$ complexes were observed to pick single representative family profile, 118 ( 12\%) were picking multiple profiles and 447 ( 44\%) complexes did not pick profile of any of the representatives.

444 new complexes which were able to pick single profiles from database of 59 profiles at Evalue $10^{-3}$ using RPS-BLAST were added as new members of the existing families and marked as representative associations in the master table of classification [see Additional file 1]. 118 complexes were observed to pick more than one representative's profile, because of the existence of more than one representative for a family and also 8 of them were ternary complexes (i.e. two proteins bound to DNA [see Additional file 2]. In the first case, when they were picking profiles of the representatives of the same family, the complex was added to that particular family. Ternary 
complexes were split into different chains and the chains were added to the respective families. There were a total of 12 complexes which were ternary in nature, three were in association with a representative and one was a loner (defined later).

447 complexes, which did not pick any of the representative profile, were checked for all pairwise associations among themselves. 369 of these were observed to form 75 families and rest 78 did not associate with any of the sequences and were termed as loners. For all these 75 families having 369 members, their functional annotations were manually recorded by consulting the literature and the newly formed different families were attributed a status within the existing eight groups and are mentioned as pairwise association [see Additional file 1]; 78 (loners) were likewise mentioned as 'singlemembered families loners' in master classification chart [see Additional file 1], loners were classified into new families by consulting literature and these references [see Additional file 3] have been marked. The new families were named according to the biological function performed by the respective members. While making these new families in existing groups, one new group ' $\beta$ propeller' was also realized. Presently, this group has single family which in-turn has two members which are DNA-bound complex of DNA damage repair protein having a seven bladed $\beta$-propeller fold.

\section{New families and their representatives}

The sequence analysis based approach for DNA-protein complexes, as described above, gave rise to classification of DNA-binding proteins into nine groups and 174 families. 59 families $(\sim 33 \%)$ have only single member, 35 (20\%) families have two members and 82 ( $47 \%)$ families are multi-member families. Figure 5 depicts the percentage distribution of single, two- or multi-member families in each of the nine groups.

The proteins included in the same group exhibit same DNA-binding motif and within the same family they have similar functional roles. The new families were identified by checking the associations of individual proteins with every other protein or with the previously classified protein. The details about the families in nine different groups and PDB codes of the members are recorded in the classification chart [see Additional file 1].

The schematic of the classification represented in Figure 6 highlights the different ways adopted to classify DNA-protein complexes. Table 2 summarizes the modifications performed in Thornton's families after association of new members. The listed families have been marked up appropriately as renamed or split or merged, as the case may be.

The following are some examples explaining the modifications made to the existing families in order to add the new members:

\section{Renaming}

While performing classification, six previously recognised families were renamed - Cro and repressor $(\mathrm{HTH}$ group), Diphtheria tox repressor (HTH group), Hormone nuclear receptor ( $\mathrm{Zn}$ co-ordinating group), Gal4 ( $\mathrm{Zn}$ co-ordinating group), Cre recombinase (Other $\alpha$-helix group) and ReI homology (Other $\alpha$-helix group). The names in parentheses indicate their modified names. Table 2 lists these families with their new name incurred upon classification.

Diphtheria tox repressor family was previously having diphtheria tox iron dependent repressor [13], which is known to regulate the toxin coding tox gene in Corynebacterium diphtheriae. This family was renamed to iron

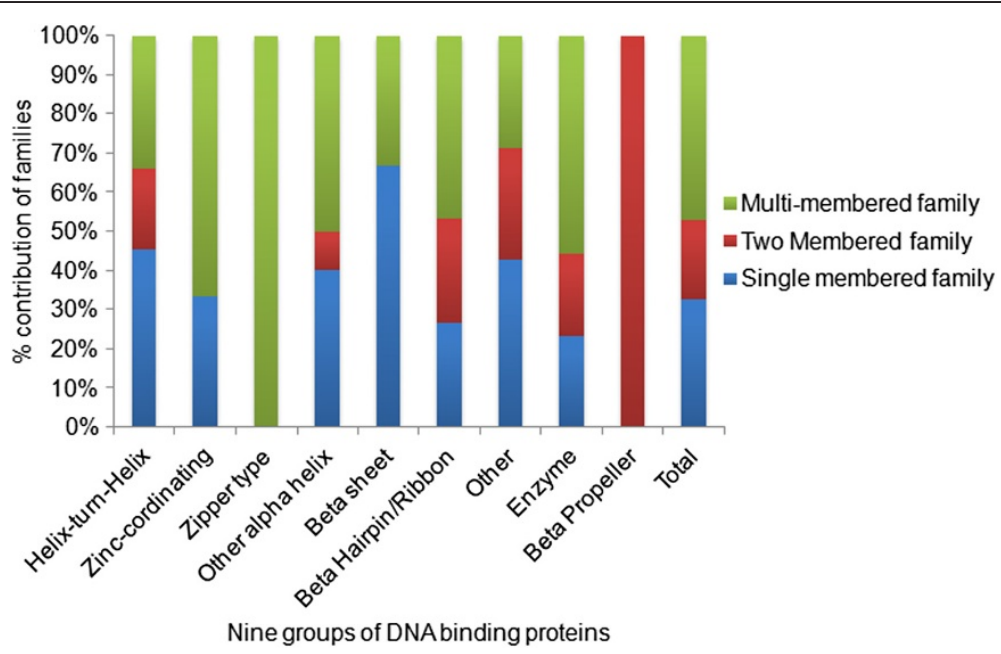

Figure 5 Percentage distribution of single, two- and multi-membered families in new classification. Percentage distribution of number of single-, two- and multi-member families in each of the nine groups. Total represents the distribution in all the groups collectively. 


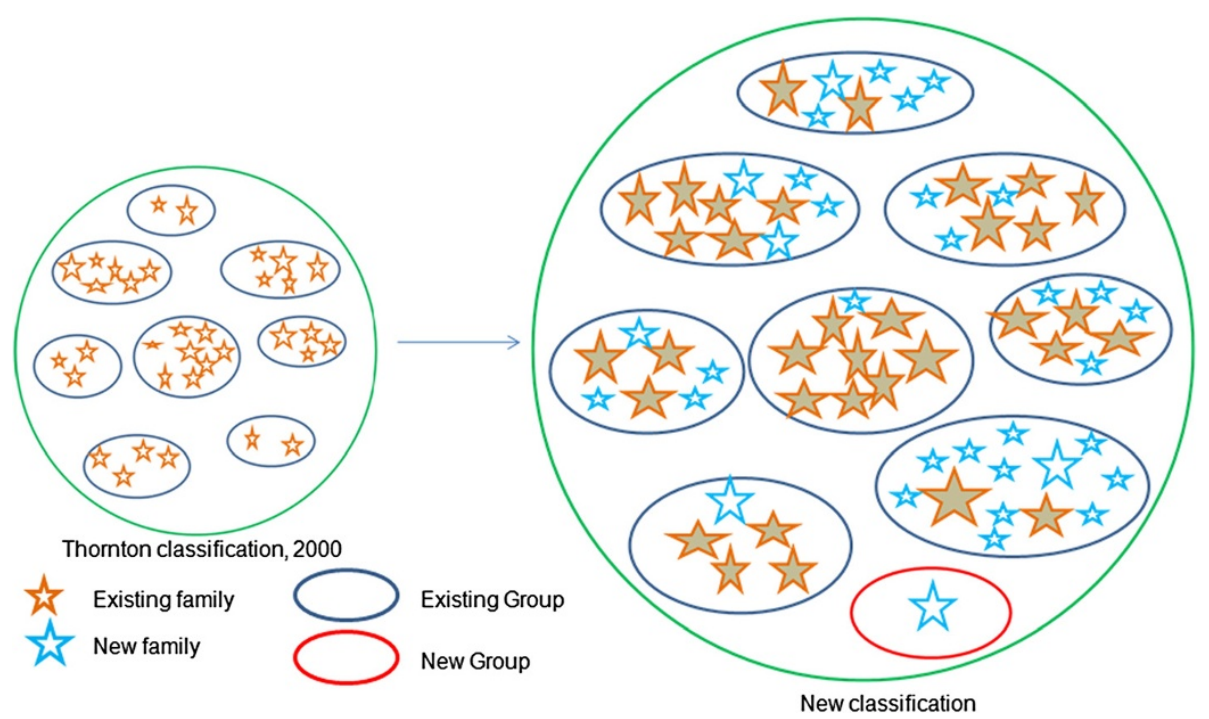

Figure 6 Schematic of the Classification. The circles represent the entire pool of DNA-protein complexes. Within the circles, ovals are the different groups of DBP; orange stars are the existing families within groups. These groups vary in their size in terms of number of families present and also the number of members within each family. After our classification, one new group was realized (red oval), also the new members were added to existing families (shaded orange ovals) and also new families were realized as represented by blue stars.

dependent repressors to include iron dependent regulator (IdeR), from Mycobacterium tuberculosis which is known to be the functional homolog of diphtheria tox repressor [14].

\section{Splitting and merging}

Previously existing families, like leucine zipper and Uracil DNA glycosylases, were split into subfamilies. Leucine zipper was observed to have two subfamilies bzip1

Table 2 Modifications in previous families

\begin{tabular}{|c|c|c|}
\hline \multirow[t]{2}{*}{ Group } & \multicolumn{2}{|r|}{ Existing Families } \\
\hline & Before classification & After classification \\
\hline \multicolumn{3}{|l|}{ HTH } \\
\hline & Cro \& repressor & Renamed to Cro and cro like \\
\hline & Diptheria tox repressor & Renamed to iron dependent repressor \\
\hline \multicolumn{3}{|c|}{ Zinc Co-ordinating } \\
\hline & Harmone Nuclear Receptor & Renamed to Nuclear receptors \\
\hline & GAL4 type & Renamed to Gal 4 and Gal 4 like \\
\hline \multicolumn{3}{|l|}{ Zipper type } \\
\hline & Leucine Zipper & Has subfamilies bzip1 and bzip2 \\
\hline \multicolumn{3}{|l|}{ Other-a Helix } \\
\hline & Cre Recombinase & Renamed to Site specific recombinases \\
\hline \multicolumn{3}{|l|}{ Other } \\
\hline & Rel homology & Renamed to Ig fold like Transcription factor \\
\hline \multicolumn{3}{|l|}{ Enzyme } \\
\hline & DNA polymerase $\beta$ & Merged and splitted into DNA Polymerase A, B, C, X and $Y$ \\
\hline & DNA Polymerase I & \\
\hline & DNA Polymerase T7 & \\
\hline & Uracil DNA glycosylase & Has 3 subfamilies Human UDG, Xenopus UDG and T. thermophilus UDG \\
\hline
\end{tabular}

The previously recognised 54 families were split, renamed or merged while classification in order to populate them with the new members. The families listed below have been marked appropriately if they were renamed or split or merged. $17 \%$ of the families underwent these treatment. (Rest of the previously recognised families which are not listed did not get change and were populated with new members). 
and bzip2. In enzymes group, uracil DNA glycosylase family was split into three subfamilies based on the source of the enzyme, human, Xenopus or Thermus thermophilus.

In the previous classification, DNA polymerases were classified in three families- DNA Pol DNA Pol I and T7 DNA Pol. After new classification, these three families were merged and then split to form five sequence-based families [15], DNA polymerase A, B, C, X and Y.

In contrast to the number of existing families in different groups, the maximum fold change in terms of increase in number of families was observed to undergo a five-fold increase in the Enzyme group. However, in groups HTH, $\beta$-sheet and 'Other', an approximately three-fold increase in the number of families was observed. Three groups, Zinc coordinating, Zipper type and Other $\alpha$-helix, were not observed to experience significant increase in the number of families during the re-classification in comparison to the number of previously existing families. Figure 7 shows the total number of families within each group before and after our classification.

The new families were also examined for their folds as ascribed to them by SCOP 1.75 [16], and the folds were recorded [see Additional file 1]. Although SCOP is a highly updated database, we realised that $\sim 30 \%$ of the entries (PDB IDs) were not included in SCOP 1.75 due to newer PDB entries. 34 SCOP folds were common to both new and old classification and they experienced an expansion in the number of complexes. The fold change in these 34 common folds is represented in Figure 8. The number of members, belonging to both old and new classification possessing each of the common 34 folds is summarised [see Additional file 4]. The top three folds, experiencing maximum expansion in terms of members possessing them, were Histone, Homing endonuclease and DNA/RNA Polymerase - truly reflecting the maximum increase in the number of members and families in enzymes group. Therefore, expansion in the existing families was seen to a maximum extent in the families of enzyme group which have property to bind to DNA and then carry out an enzymatic activity.

Also, there were 28 folds which were present only in new complexes, suggesting emergence of structures of complexes performing new functions (Figure 9). The proteins possessing DNA-repair function is present exclusively in the newly classified complexes like Y-family DNA polymerases which are known to bypass a lesion in DNA, DNA glycosylases and MutS DNA-repair proteins.

It was observed that for all the groups, in total, there were 57 single-member, 35 two- member and 82 multimember families. New representatives were also selected for these 174 new families. For 57 single-member families, the member itself was a representative. In twomember families, equal chance to each member was given to become a representative and the one having $100 \%$ coverage was selected as representative. For multi-

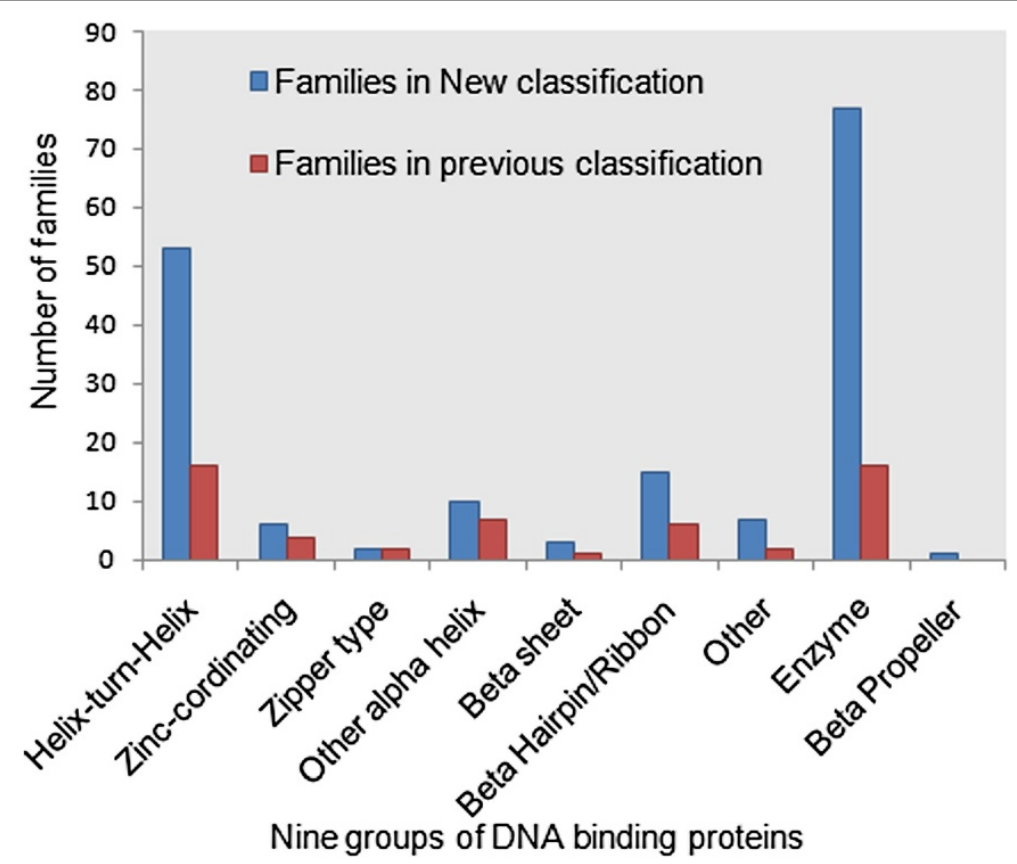

Figure 7 Distribution of number of families in different groups in both old and new classification. Total number of families in each group before and after new classification. The highest increase was observed to be the five-fold increase in the total number of families in Enzyme group. 

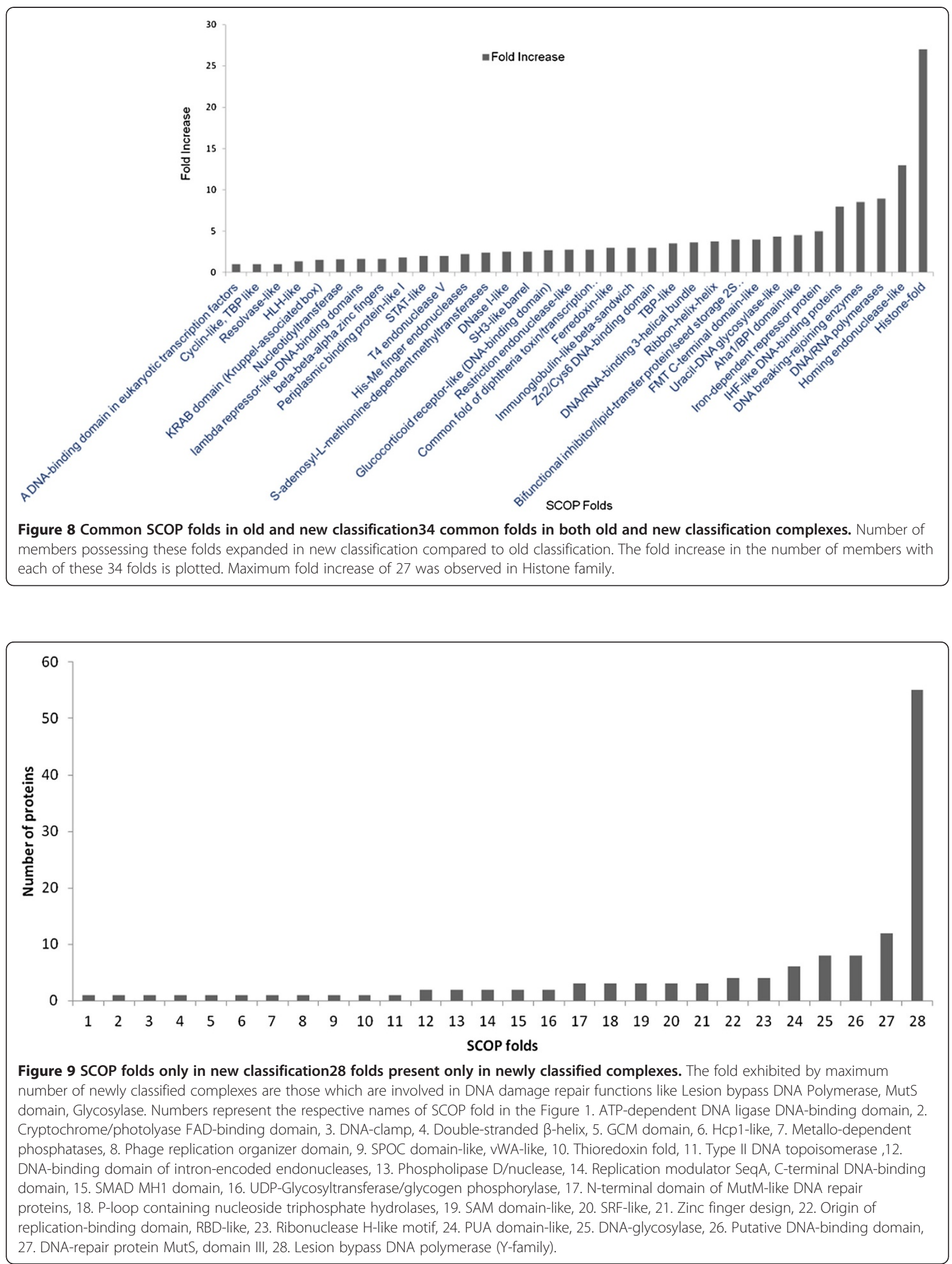
member families, the pairwise percentage identity distribution in the form of box-plot is represented in Figure 10. Out of 82 multi-member families, 32 were observed as having narrow percent identity distribution, whereas 50 families (marked with star Figure 10) were having wide distribution of percentage identity. For 47 families, leave-one-out approach was adopted to find best representative. There were three families (out of 50) with

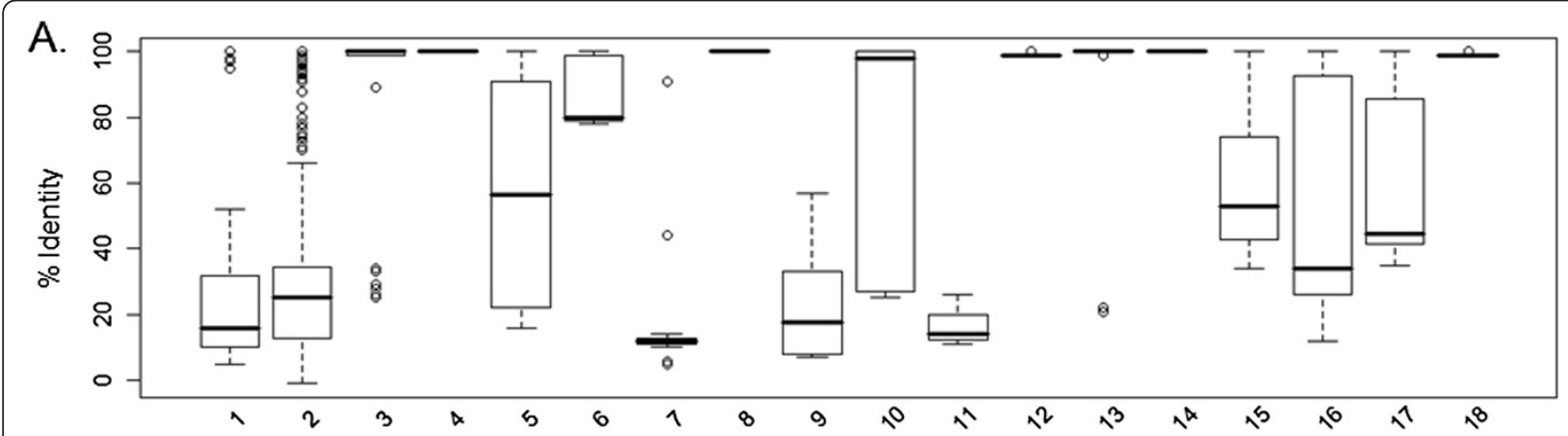

B.

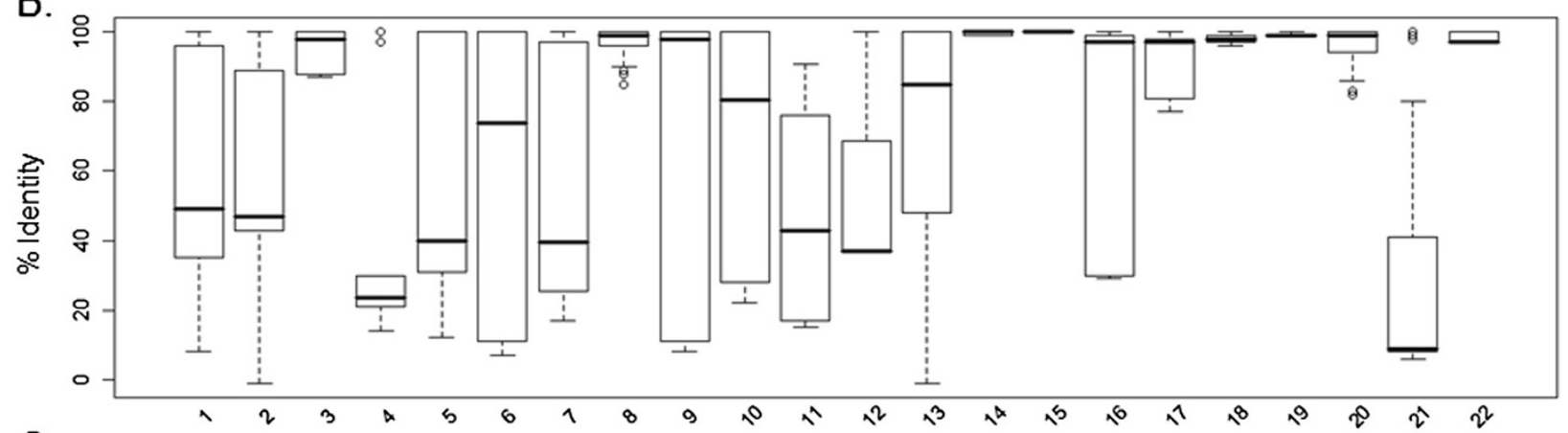

C.

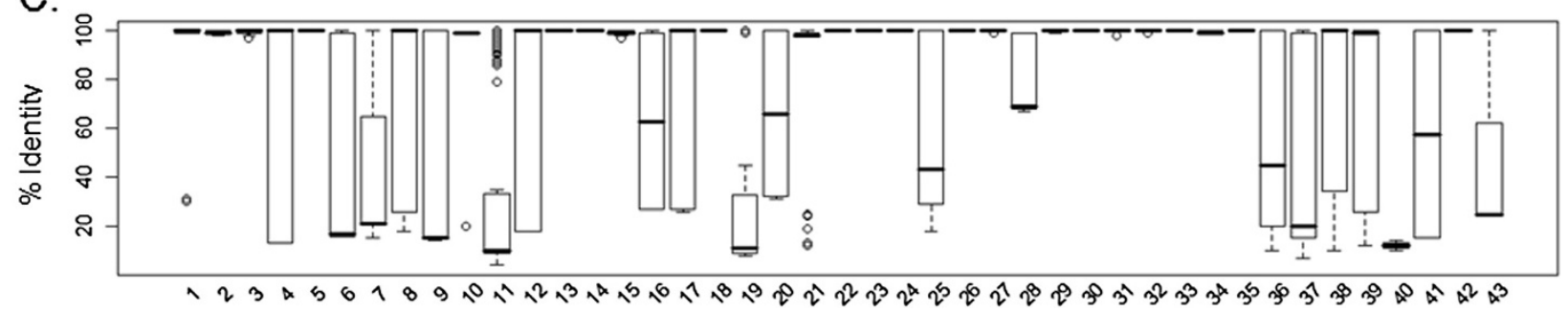

Figure 10 Pairwise percentage identity distribution for new families. (A). Boxplot for pairwise percent distribution for 18 multi-member families of group HTH, the following are the family names 1. ${ }^{*} \mathrm{Cr}$ and Cro like 2. *Homeodomain 3. Lacl repressor 4. Hin recombinase $5 .{ }^{*}$ RAP1 6. *Iron Dependent repressor 7. * Transcription factor IIB/IIA 8. NarL transcription factor 9. *Tn5 Transposase 10. *MutS 11. *Tetracycline Repressor 12. Interferon regulatory factor $13 .{ }^{*}$ Catabolite gene activator protein 14. Transcription factor $15 .{ }^{*}$ Ets domain $16 .{ }^{*} Z$-a domain $17 .{ }^{*}$ Forkhead TF 18. Transcription activator BMRR (B). Boxplot for pairwise percent distribution for $20^{*}$ multi-member families of group Zinc co-ordinating, Zipper type, Other $\alpha$-helix, $\beta$-sheet, $\beta$-hairpin/ribbon and Other. The following are the family names- 1 . *Zinc-coordinating- $\beta$ - $\beta$ - $\alpha$-zinc finger 2.

*Zinc-coordinating-Nuclear Receptors 3. *Zinc-coordinating-Loop-sheet-helix 4. *Zinc-coordinating-gal4 5. *Zipper-type-bzip1 6. *Zipper-type-bzip2 7. *Zipper-type-Helix-loop-helix 8. 80ther a-helix -histone 9. *Other a-helix -Site specific recombinases 10. *Other a-helix -High mobility group 11. Other a-helix -MADS box 12. *Other a-helix -CUT domain 13. * $\beta$-sheet-TATA box-binding 14. * $\beta$-hairpin-MetJ repressor $15 . \beta$-hairpin-Tus replication terminator 16. * $\beta$-hairpin-Integration host factor 17. * $\beta$-hairpin-Hyperthermophile DNA-BP 18. * $\beta$-hairpin-Arc repressor 19. $\beta$-hairpin-Omega Repressor 20. * $\beta$-hairpin-SRA Domain 21. *Other-lg fold like TF 22. *Other-Seq A*Total number of plots are 21 in Figure $9(B)$ as bzip1 and bzip2 boxplots are different but they are subfamilies of single Leucine zipper family (C). Boxplot for pairwise percent distribution for 43 multi-member families of group enzymes. The following are the family names- 1. Methyltransferase 2. Endonuclease Pvull 3. Endonuclease ecorV 4. *Endonuclease ecorl 5. Endonuclease BamHI 6. *Enonuclease V 7. *Dnase I 8. *HIV reverse transcriptase 9. *Uracil-DNA glycosylase 10. 3-Methyladenine DNA glycosylase 11. *Homing endonuclease 12. *Topoisomerase I 13. T7 RNA Pol 14. N4 RNA Pol 15. Hincll restriction endonuclease 16. *Endonuclease III and MutY 17. *DNA Photolyase 18. a-glucosyl transferase 19. *Helicase 20. *Thymine DNA-glycosylase 21. 8-oxoguanine DNA glycosylase 22. ALKA 23. Phi 6 RNA Pol 24. $\beta$-Glucosyltransferase 25. *Endonuclease VIII and MutM 26. Human tyrosyl-DNA phosphodiesterase 27. Relaxase TrwC 28. *Nuclease-Colicin 29. Endonuclease IV 30. Excisionase (Xis) 31. ISHp608 Transposase 32. AlkB 33. Restriction Endonuclease HinP1I 34. ABH2 35. Restriction endonuclease SgrAl 36. *Family A Polymerases 37. *Family B Polymerases 38 . *Family $\mathrm{X}$ Polymerases 39. *Family Y Polymerases 40. *DNA Ligase 41. *Family C polymerases 42. Mtaq 1 methylase 43.* DAM(Stars in front of the family name implies it has wide distribution of percent identity and further the family was subjected to Jack-knifing for selecting the representative). 
wide percentage identities with $>50$ members- Family A DNA Pol, Family X DNA Pol and Family Y DNA Pol, where clustering was performed followed by assessing the representative from every cluster both individually and in combination to assess its coverage.

\section{Old vs. new representatives}

While selecting the new representatives, care was taken to retain the previously chosen representative, if it showed $100 \%$ coverage for the family including the newly added members. As a result, it was observed that $75 \%$ (for 38 families out of 51) of the previously chosen representatives were retained as family representatives even after adding the new members [see Additional file 5]. In total, 191 representatives were identified for 174 families [see Additional file 6].

\section{Conclusions}

Protein nucleic acid complexes form the most vital interacting macromolecular pairs existing in the biological cell. It governs number of cellular processes and hence helps in maintaining the normal physiological state of the cell.

Here, we have investigated the existing DNA-protein complexes in the PDB (Feb2010) and provided a systematic two-tier protein-centric classification for them. To achieve this, we have looked upon and studied the existing classification [1]. But due to nearly exponentially increasing growth of PDB [17], there is a need to revisit the existing classification.

The main features of the classification we propose are:

1. The number of complexes classified is $\sim 5$ times (1009 vs. 230) more than the number of DNAprotein complexes classified previously. There were approximately equal number of complexes from prokaryotic as well as eukaryotic sources, but only little above $11 \%$ of the complexes were having viral proteins.

2. It is a two-tier classification at group and family level. At the first level, group defines the DNA-binding motif present except in the Enzyme group, where any protein with the capability to bind to DNA and exhibiting enzymatic activity was placed. At the family level, proteins were grouped on the basis of their biological function by checking associations of individual proteins with each other or with the previously classified protein.

3. A new group ' $\beta$-Propeller' is brought in, presently having only one family- DDB1-DDB2, which plays a role in UV DNA damage recognition using its seven bladed $\beta$-propeller [18].

4. The number of families has increased to $\sim 3$ times (174 vs. 54) by virtue of the increase in the number of DNA-protein complexes deposited in PDB (a 60\% increase with respect to increasing entries of DNAbound protein complexes in $\mathrm{PDB}$ ). There was a fivefold increase in the number of families in Enzyme group alone and this was accompanied by a large increase in the number of complexes (number of complexes in Enzymes group increased to 714 from Thornton's 113) in Enzyme group after our classification. $\sim 67 \%$ families have more than one member in the new classification. This indicates some groups are growing fast in terms of the family numbers faster than the others, which can be explained due to several reasons. Firstly, this can be due to the higher utilisation of some DNA-binding motifs over the other: for example, helix-turn-helix motif is most frequently represented motif. However, the group of Enzymes has more families due to the diverse nature of biological function performed by the proteins which possess catalytic activity upon binding DNA. Secondly, there are some specific motifs like Zipper type which are meant to perform not-so-diverse functions so the numbers of families in such groups tend to be less. There is also an inherent bias or preference for certain structure targets that affects the number of families in the group. For example, presently in the field more emphasis is on DNA-repair proteins, proteins with implications in diseases etc.

While performing classification, $17 \%$ of the existing families were observed to have undergone either splitting or renaming in order to make add more complexes to the family (Percentage marked, Table 2). The analysis of folds present in complexes of old and new classification reflected that maximum fold increase was in Histone and then in folds which are present in enzymes like Homing endonuclease-like, DNA/RNA Polymerase and DNA-breaking and rejoining.

There were also new folds observed which were present only in new complexes. This is suggestive of the growth of PDB over a year of 10 years, both in terms of number of complexes and the folds present in the structures which are getting deposited. The folds which were noted to appear only in the new classification were ones known to perform function of DNA damage repair like DNA glycosylase, Lesion bypass DNA Polymerase (Y-family) and Mut S domain.

The classification of DNA-binding proteins will provide a very useful insight in exploring further the sequenceto-structure-to-function paradigm, also about the interaction between protein and its respective DNA partner to govern and fine-tune the effecter function of the cell. The current classification will help to understand the given complex of interest in terms of to which group 
(DNA-binding motif) and family (biological function) it belongs to.

Unlike the structure-based classification by Thornton and coworkers, that formed a strong platform for the current study, we have now adopted a pure sequencebased classification strategy owing to the large number of structural entries added on. Also, due to strong structural convergence and fine-tuned sequence changes in and near the ligand-binding site, simple structural comparisons may be insufficient in some cases. To compare our approach with the structural alignment methods, we are highlighting an example where it is difficult to decide the cut-off RMSD value for a particular family [see Additional files 7, 8 and 9], wherein all neighbouring families which are reported to have same SCOP fold i.e. DNA/ RNA binding three-helical bundle.

We performed a case study on Homeodomain family belonging to Helix-turn-helix group. All pairwise structural alignments for 34 members in Homeodomain family was performed using rigid-body superposition and the pairwise RMSD values are depicted in Additional file 7 (7 entries out of 34 were heterodimers and for them chains were split and then the structural alignment was performed, resulting in overall 41 chains and 820 pairwise alignments). For PDB ID 1JGG (marked in green, [see Additional file 7]), RMSD with five of its own classified family members was observed to be $>2 \AA$. The RMSD value of $2 \AA$ was also observed for 1 JGG, in a non-specific manner, with representative for another family Trp Repressor (HTH group, same SCOP as Homeodomain), 1TRR. Also, RMSD of $2.1 \AA$ was observed between 1JGG and 1TC3 (Representative for family TC3 transposase family, HTH group and have same SCOP fold as Homeodomain) (Additional file 9). This exemplifies that RMSD values as a result of structural alignment can pose a difficulty in deciding a cut-off value for a particular family and may not be a useful single determinant for association of new entries to previously existing protein structural entries. On the other hand, if we compare it with our profile-based approach using RPS-BLAST, 1JGG was observed to associate specifically only to the profile of Homeodomain proteins namely 1FJL (at E-value $3 \mathrm{e}^{-8}$ ) and 1HDD (at E-value 6e $\mathrm{e}^{-13}$ ) [see Additional file 8]. By observing the structural alignment and RMSD values alone for above mentioned pairs, it becomes difficult to identify a particular family member (all RMSD values $>=2.5 \AA$ (47 pairwise RMSD) are marked in red [see Additional file 7]).

Next, we applied RPS-BLAST to associate large number of gene products with our database of sequences of proteins that bind to DNA. Where simple approaches like PSI-BLAST was not able to identify associations to DNA-protein families, RPS-BLAST and HMM methods provide unique associations when run on the whole genome of Arabidopsis thaliana [see Additional file 10]. We also hope that such searches can be extended to sequence-centric databases like genomes of model organisms in the future.

In future, this classification can aid in performing several genome-wide studies which can be performed in various genomes of interest to study the expansion or disappearance of a particular family in specific lineage. This will provide an insight into various modes of regulation existing in different lineages at the level of proteins known to interact with DNA. Also, utilizing the various features of all DNA-binding proteins, SVMbased machine learning algorithms can be developed to predict whether a sequence of interest exhibits DNAbinding property or not. We can make even more specific predictions, such as given protein sequence belongs to which particular group and family can be identified by extracting the family specific features. Also, classification can be extended to include sequence families of DNA binding proteins which will aid in complete understanding of the features of this class of proteins. It will also be worthwhile to build classification schemes for other proteins which are involved in governing cellular integrity and its function.

\section{Additional files}

\begin{abstract}
Additional file 1: Master table of the classification. Association of additional and new members to pre-existing families.

Additional file 2: List of references that describe 'loners' proteinDNA complex [19-92].

Additional file 3: Ternary protein-DNA complexes.

Additional file 4: The number of complexes in both old and new classification possessing each of the common 34 folds.

Additional file 5: New vs. Old representatives. $38 / 51^{*}$ cases where old representative was still observed to have $100 \%$ coverage on the family even after addition of new members. *The number of old families here is 54 but here it is taken as 51 as the three polymerase families (T7 DNA Pol, DNA Pol $\beta$ and DNA Pol I) were split in the new classification.

Additional file 6: Representatives for new families. New families with their selected representatives (validated using Jack-knifing).

Additional file 7: Pairwise RMSD values obtained using MATT for all members of Homeodomain family belonging to HTH group.

Additional file 8: RPS-BLAST alignment of new member of Homeodomain family (1JGG) with Homeodomain representatives (1HDD and 1FJL).

Additional file 9: Structural superposition using MATT. Structural alignment for 1JGG (Homeodomain new member) with 1TRR (Trp Repressor representative), 1TC3 (Tc3 transposase representative) and 6PAX (Homeodomain representative)].

Additional file 10: Unique hits obtained by profile-based methods. Some examples of DNA-binding proteins identified using only profilebased searches are observed during genome-wide survey in Arabidopsis thaliana.
\end{abstract}

\section{Competing interests}

The author declares that they have no competing interests. 


\section{Authors' contributions}

RS designed the project and conceived the experiments. SM carried out coding and scripting and performed the entire analysis. SM drafted the manuscript and RS provided critical comments to improve it. All authors read and approved the final manuscript.

\section{Acknowledgements}

S.M. thanks Department of Biotechnology (India) for her studentship. R.S. was a Senior Research Fellow of the Wellcome Trust (U.K.). We thank NCBS (TIFR) for infrastructure and other facilities.

Received: 12 July 2011 Accepted: 26 March 2012

Published: 16 July 2012

\section{References}

1. Luscombe NM, Austin SE, Berman HM, Thornton JM: An overview of the structures of protein-DNA complexes. Genome Biol 2000, 1. reviews001.1-001.37.

2. Mandel-Gutfreund $\mathrm{Y}, \mathrm{Schueler} \mathrm{O}$, Margalit $\mathrm{H}$ : Comprehensive analysis of hydrogen bonds in regulatory protein DNA-complexes: in search of common principles. J Mol Biol 1995, 253:370-382.

3. Luscombe NM, Laskowski RA, Thornton JM: Amino acid-base interactions: a three-dimensional analysis of protein-DNA interactions at an atomic level. Nucleic Acids Res 2001, 29:2860-2874.

4. Reddy CK, Das A, Jayaram B: Do water molecules mediate protein-DNA recognition? J Mol Biol 2001, 314:619-632.

5. Harrison SC: A structural taxonomy of DNA-binding domains. Nature 1991, 353:715-719.

6. Ponomarenko JV, Bourne PE, Shindyalov IN: Building an automated classification of DNA-binding protein domains. Bioinformatics 2002, 18(Suppl 2):S192-201.

7. Prabakaran P, Siebers JG, Ahmad S, Gromiha MM, Singarayan MG, Sarai A: Classification of protein-DNA complexes based on structural descriptors. Structure 2006, 14:1355-1367.

8. Sen TZ, Kloczkowski A, Jernigan RL: A DNA-centric look at protein-DNA complexes. Structure 2006, 14:1341-1342.

9. Berman HM, Westbrook J, Feng Z, Gilliland G, Bhat TN, Weissig H, Shindyalov IN, Bourne PE: The Protein Data Bank. Nucleic Acids Res 2000 28:235-242.

10. Altschul SF, Madden TL, Schäffer AA, Zhang J, Zhang Z, Miller W, Lipman DJ: Gapped BLAST and PSI-BLAST: a new generation of protein database search programs. Nucleic Acids Res 1997, 25:3389-3402.

11. Marchler-Bauer A, Panchenko AR, Shoemaker BA, Thiessen PA, Geer LY, Bryant SH: CDD: a database of conserved domain alignments with links to domain three-dimensional structure. Nucleic Acids Res 2002, 30:281-283.

12. Jeanmougin F, Thompson JD, Gouy M, Higgins DG, Gibson TJ: Multiple sequence alignment with Clustal X. Trends Biochem Sci 1998, 23:403-405.

13. Schmitt MP, Holmes RK: Iron-dependent regulation of diphtheria toxin and siderophore expression by the cloned Corynebacterium diphtheriae repressor gene dtxR in C. diphtheriae C7 strains. Infect Immun 1991, 59:1899-1904

14. Schmitt MP, Predich M, Doukhan L, Smith I, Holmes RK: Characterization of an iron-dependent regulatory protein (IdeR) of Mycobacterium tuberculosis as a functional homolog of the diphtheria toxin repressor (DtxR) from Corynebacterium diphtheriae. Infect Immun 1995, 63:4284-4289.

15. Ito J, Braithwaite DK: Compilation and alignment of DNA polymerase sequences. Nucleic Acids Res 1991, 19:4045-4057.

16. Murzin AG, Brenner SE, Hubbard T, Chothia C: SCOP: a structural classification of proteins database for the investigation of sequences and structures. J Mol Biol 1995, 247:536-540.

17. Täubig H, Buchner A, Griebsch J: PAST: fast structure-based searching in the PDB. Nucleic Acids Res 2006, 34:W20-23.

18. Scrima A, Konícková R, Czyzewski BK, Kawasaki Y, Jeffrey PD, Groisman R, Nakatani Y, Iwai S, Pavletich NP, Thomä NH: Structural basis of UV DNAdamage recognition by the DDB1-DDB2 complex. Cell 2008, 135:1213-1223.

19. lyaguchi D, Yao M, Watanabe N, Nishihira J, Tanaka I: DNA Recognition Mechanism of the ONECUT Homeodomain of Transcription Factor HNF6. Structure 2007, 15:75-83. doi:10.1016/j.str.2006.11.004.
20. Chi Y, Frantz JD, Oh B, Hansen L, Dhe-Paganon S, Shoelson SE: Diabetes mutations delineate an atypical POU domain in HNF-1alpha. Mol Cell 2002, 10:1129-1137.

21. Yousef MS, Matthews BW: Structural basis of Prospero-DNA interactionimplications for transcription regulationin developing cells Structure 2005, 13:601-607. doi:10.1016/j.str.2005.01.023.

22. Tawaramoto MS, Park S, Tanaka Y, Nureki O, Kurumizaka H, Yokoyama S: Crystal structure of the human centromere protein B (CENP-B) dimerization domain at 1.65-A resolution. J Biol Chem 2003, 278:51454-51461. doi:10.1074/jbc.M310388200.

23. Orth $P$, Schnappinger D, Hillen W, Saenger W, Hinrichs W: Structural basis of gene regulation by the tetracycline inducible Tet repressor-operator system. Nat Struct Biol 2000, 7:215-219. doi:10.1038/73324.

24. Schumacher MA, Miller MC, Grkovic S, Brown MH, Skurray RA, Brennan RG: Structural basis for cooperative DNA binding by two dimers of the multidrug-binding protein QacR. EMBO J 2002, 21:1210-1218. doi:10.1093/ emboj/21.5.1210.

25. Itou H, Watanabe N, Yao M, Shirakihara Y, Tanaka I: Crystal structures of the multidrug binding repressor Corynebacterium glutamicum CgmR in complex with inducers and with an operator. J Molecular Biol 2010, 403:174-184. doi:10.1016/j.jmb.2010.07.042.

26. Komori H, Matsunaga F, Higuchi Y, Ishiai M, Wada C, Miki K: Crystal structure of a prokaryotic replication initiator protein bound to DNA at 2.6 A resolution. EMBO J 1999, 18:4597-4607. doi:10.1093/emboj/ 18.17.4597.

27. Schumacher MA, Funnell BE: Structures of ParB bound to DNA reveal mechanism of partition complex formation. Nature 2005, 438:516-519. doi:10.1038/nature04149.

28. Williams CE, Grotewold E: Differences between plant and animal Myb domains are fundamental for DNA binding activity, and chimeric Myb domains have novel DNA binding specificities. J Biol Chem 1997, 272:563-571.

29. König B, Müller JJ, Lanka E, Heinemann U: Crystal structure of KorA bound to operator DNA: insight into repressor cooperation in RP4 gene regulation. Nucleic Acids Res 2009, 37:1915-1924. doi:10.1093/nar/gkp044.

30. Shen A, Higgins DE, Panne D: Recognition of at-rich DNA binding sites by the MogR repressor. Structure 2009, 17:769-777. doi:10.1016/j. str.2009.02.018

31. Lee KS, Bumbaca D, Kosman J, Setlow P, Jedrzejas MJ: Structure of a protein-DNA complex essential for DNA protection in spores of Bacillus species. Proc Nat Acad Sci 2008, 105:2806.

32. Lane WJ, Darst SA: The structural basis for promoter -35 element recognition by the group IV sigma factors. PLoS Biol 2006, 4:e269. doi:10.1371/journal.pbio.0040269.

33. Fuhrmann J, Schmidt A, Spiess S, Lehner A, Turgay K, Mechtler K, Charpentier $E$, Clausen T: McsB is a protein Arginine Kinase that Phosphorylates and inhibits the heat-shock regulator CtsR. Science 2009, 324:1323-1327. doi:10.1126/science.1170088

34. McGeehan JE, Streeter SD, Thresh SJ, Ball N, Ravelli RB, Kneale GG: Structural analysis of the genetic switch that regulates the expression of restriction-modification genes. Nucleic Acids Res 2008, 36:4778.

35. Fujikawa N, Kurumizaka H, Nureki O, Terada T, Shirouzu M, Katayama T, Yokoyama S: Structural basis of replication origin recognition by the DnaA protein. Nucleic Acids Res 2003, 31:2077-2086.

36. Zhao H, Msadek T, Zapf J, Madhusudan, Hoch JA, Varughese KI: DNA complexed structure of the key transcription factor initiating development in sporulating bacteria. Structure 2002, 10:1041-1050

37. Khare D, Ziegelin G, Lanka E, Heinemann U: Sequence-specific DNA binding determined by contacts outside the helix-turn-helix motif of the ParB homolog KorB. Nat Struct Mol Biol 2004, 11:656-663. doi:10.1038/ nsmb773.

38. He C, Hus J, Sun $\amalg$, Zhou P, Norman DPG, Dötsch V, Wei H, Gross JD, Lane WS, Wagner G, Verdine GL: A methylation-dependent electrostatic switch controls DNA repair and transcriptional activation by E. coli ada. Mol Cell 2005, 20:117-129. doi:10.1016/j.molcel.2005.08.013.

39. Ha SC, Kim D, Hwang HY, Rich A, Kim YG, Kim KK: The crystal structure of the second Z-DNA binding domain of human DAI (ZBP1) in complex with Z-DNA reveals an unusual binding mode to Z-DNA. Proc Nat Acad Sci 2008, 105:20671.

40. Ha SC, Lokanath NK, Van Quyen D, Wu CA, Lowenhaupt K, Rich A, Kim Y, Kim KK: A poxvirus protein forms a complex with left-handed Z-DNA: 
crystal structure of a Yatapoxvirus Zalpha bound to DNA. Proc Natl Acad Sci USA 2004, 101:14367-14372. doi:10.1073/pnas.0405586101.

41. Schumacher MA, Lau AOT, Johnson PJ: Structural basis of core promoter recognition in a primitive eukaryote. Cell 2003, 115:413-424.

42. Yokoyama K, Ishijima SA, Koike H, Kurihara C, Shimowasa A, Kabasawa M, Kawashima T, Suzuki M: Feast/famine regulation by transcription factor FL11 for the survival of the Hyperthermophilic Archaeon Pyrococcus OT3. Structure 2007, 15:1542-1554. doi:10.1016/.str.2007.10.015.

43. Huang N, De Ingeniis J, Galeazzi L, Mancini C, Korostelev YD, Rakhmaninova $A B$, Gelfand MS, Rodionov DA, Raffaelli N, Zhang H: Structure and function of an ADPRibose- dependent transcriptional regulator of NAD metabolism. Structure 2009, 17:939-951. doi:10.1016/j.str.2009.05.012.

44. Cherney LT, Cherney MM, Garen CR, Lu GJ, James MN: Crystal structure of the arginine repressor protein in complex with the DNA operator from Mycobacterium tuberculosis. J Mol Biol 2008, 384:1330-1340.

45. Garnett JA, Marincs F, Baumberg S, Stockley PG, Phillips SEV: Structure and function of the arginine repressor-operator complex from Bacillus subtilis. J Mol Biol 2008, 379:284-298. doi:10.1016/j.jmb.2008.03.007.

46. Gajiwala KS, Chen H, Cornille F, Roques BP, Reith W, Mach B, Burley SK: Structure of the winged-helix protein hRFX1 reveals a new mode of DNA binding. Nature 2000, 403:916-921. doi:10.1038/35002634.

47. Blanco AG, Sola M, Gomis-Rüth FX, Coll M: Tandem DNA recognition by $\mathrm{PhoB}$, a two-component signal transduction transcriptional activator. Structure 2002, 10:701-713.

48. Watanabe S, Kita A, Kobayashi K, Miki K: Crystal structure of the [2Fe-2S] oxidativestress sensor SoxR bound to DNA. Proc Natl Acad Sci USA 2008, 105:4121-4126. doi:10.1073/pnas.0709188105.

49. Schumacher MA, Hurlburt BK, Brennan RG: Crystal structures of SarA, a pleiotropic regulator of virulence genes in S. aureus. Nature 2001, 409:215-219.

50. Sabogal A, Lyubimov AY, Corn JE, Berger JM, Rio DC: THAP proteins target specific DNA sites through bipartite recognition of adjacent major and minor grooves. Nat Struct Mol Biol 2009, 17:117-123. doi:10.1038/ nsmb.1742.

51. Bates DL, Chen Y, Kim G, Guo L, Chen L: Crystal structures of multiple GATA zinc fingers bound to DNA reveal new insights into DNA recognition and self-association by GATA. J. Mol. Biol 2008, 381:1292-1306. doi:10.1016/j.jmb.2008.06.072.

52. Cohen SX, Moulin M, Hashemolhosseini S, Kilian K, Wegner M, M Uüller CW: Structure of the GCM domain-DNA complex: a DNA-binding domain with a novel fold and mode of target site recognition. EMBO J 2003, 22:1835-1845.

53. Schumacher MA: The Structure of a CREB bZIPmiddle dotSomatostatin CRE complex reveals the basis for selective dimerization and divalent cation-enhanced DNA Binding. J Bioll Chem 2000, 275:35242-35247. doi:10.1074/jbc.M007293200.

54. Fujii Y, Shimizu T, Toda T, Yanagida M, Hakoshima T: Structural basis for the diversity of DNA recognition by bZIP transcription factors. Nat Struct Mol Biol 2000, 7:889-893.

55. Kurokawa H, Motohashi H, Sueno S, Kimura M, Takagawa H, Kanno Y, Yamamoto M, Tanaka T: Structural Basis of Alternative DNA Recognition by Maf Transcription Factors. Mol Cell Biol 2009, 29:6232-6244. doi:10.1128/MCB.00708-09.

56. Longo A, Guanga GP, Rose RB: Crystal Structure of E47-NeuroD1/Beta2 bHLH Domain-DNA Complex: Heterodimer Selectivity and DNA Recognition. Biochemistry 2008, 47:218-229. doi:10.1021/bi701527r.

57. Bradley CM, Ronning DR, Ghirlando R, Craigie R, Dyda F: Structural basis for DNA bridging by barrier-to-autointegration factor. Nat Struct Mol Biol 2005, 12:935-936. doi:10.1038/nsmb989.

58. Albert A, Muñoz-Espín D, Jiménez M, Asensio JL, Hermoso JA, Salas M, Meijer WJJ: Structural basis for membrane anchorage of viral phi29 DNA during replication. J Biol Chem 2005, 280:42486-42488. doi:10.1074/jbc. C500429200.

59. Lindner SE, De Silva EK, Keck JL, Llinás M: Structural determinants of DNA binding by a P. falciparum ApiAP2 transcriptional regulator. J Mol Biol 2010, 395:558-567.

60. Sidote DJ, Barbieri CM, Wu T, Stock AM: Structure of the Staphylococcus aureus AgrA LytTR domain bound to DNA reveals a beta fold with an unusual mode of binding. Structure 2008, 16:727-735. doi:10.1016/j. str.2008.02.011.
61. Schumacher MA, Glover TC, Brzoska AJ, Jensen SO, Dunham TD, Skurray RA, Firth N: Segrosome structure revealed by a complex of ParR with centromere DNA. Nature 2007, 450:1268-1271. doi:10.1038/nature06392.

62. Zhou Y, Larson JD, Bottoms CA, Arturo EC, Henzl MT, Jenkins JL, Nix JC, Becker DF, Tanner JJ: Structural basis of the transcriptional regulation of the proline utilization regulon by multifunctional PutA. J Mol Biol 2008, 381:174-188. doi:10.1016/j.jmb.2008.05.084.

63. Min J, Pavletich NP: Recognition of DNA damage by the Rad4 nucleotide excision repair protein. Nature 2007, 449:570-575. doi:10.1038/nature06155.

64. Walker JR, Corpina RA, Goldberg J: Structure of the Ku heterodimer bound to DNA and its implications for double-strand break repair. Nature 2001, 412:607-614. doi:10.1038/35088000

65. Ho KL, McNae IW, Schmiedeberg L, Klose RJ, Bird AP, Walkinshaw MD: MeCP2 Binding to DNA Depends upon Hydration at Methyl-CpG. Mol Cell 2008, 29:525-531. doi:10.1016/j.molcel.2007.12.028.

66. Badia D, Camacho A, Pérez-Lago L, Escandon C, Salas M, Coll M: The Structure of Phage 29 Transcription Regulator p4-DNA Complex Reveals an N-Hook Motif for DNA Binding. Mol cell 2006, 22:73-81.

67. Metz AH, Hollis T, Eichman BF: DNA damage recognition and repair by 3-methyladenine DNA glycosylase I (TAG). EMBO J 2007, 26:2411-2420. doi:10.1038/sj.emboj.7601649.

68. Spiegel PC, Chevalier B, Sussman D, Turmel M, Lemieux C, Stoddard BL: The structure of I-Ceul homing endonuclease: Evolving asymmetric DNA recognition from a symmetric protein scaffold. Structure 2006, 14:869-880. doi:10.1016/j.str.2006.03.009.

69. Shen BW, Landthaler M, Shub DA, Stoddard BL: DNA binding and cleavage by the HNH homing endonuclease I-Hmul. J Mol Biol 2004, 342:43-56. doi:10.1016/.jmb.2004.07.032.

70. Frei C, Gasser SM: RecQ-like helicases: the DNA replication checkpoint connection. J Cell Sci 2000, 113(Pt 15):2641-2646.

71. Faucher F, Wallace SS, Doublié S: The C-terminal lysine of Ogg2 DNA glycosylases is a major molecular determinant for guanine/8-oxoguanine distinction. J Mol Biol 2010, 397:46-56. doi:10.1016/j.jmb.2010.01.024.

72. Hashimoto H, Shimizu T, Imasaki T, Kato M, Shichijo N, Kita K, Sato M: Crystal structures of type II restriction endonuclease EcoO109l and its complex with cognate DNA. J Biol Chem 2005, 280:5605-5610. doi:10.1074/ jbc.M411684200.

73. Newman M, Murray-Rust J, Lally J, Rudolf J, Fadden A, Knowles PP, White MF, McDonald NQ: Structure of an XPF endonuclease with and without DNA suggests a model for substrate recognition. EMBO J 2005, 24:895-905. doi:10.1038/sj.emboj.7600581.

74. Biertümpfel C, Yang W, Suck D: Crystal structure of T4 endonuclease VII resolving a Holliday junction. Nature 2007, 449:616-620. doi:10.1038/ nature06152.

75. Sukackaite R, Grazulis S, Bochtler M, Siksnys V: The recognition domain of the Bpull restriction endonuclease in complex with cognate DNA at 1.3A resolution. J Mol Biol 2008, 378:1084-1093. doi:10.1016/j.jmb.2008.03.041.

76. Deibert M, Grazulis S, Janulaitis A, Siksnys V, Huber R: Crystal structure of Munl restriction endonuclease in complex with cognate DNA at $1.7 \mathrm{~A}$ resolution. EMBO J 1999, 18:5805-5816. doi:10.1093/emboj/18.21.5805.

77. van der Woerd MJ, Pelletier JJ, Xu S, Friedman AM: Restriction enzyme BsoBI-DNA complex: a tunnel for recognition of degenerate DNA sequences and potential histidine catalysis. Structure 2001, 9:133-144.

78. Newman M, Lunnen K, Wilson G, Greci J, Schildkraut I, Phillips SE: Crystal structure of restriction endonuclease Bgll bound to its interrupted DNA recognition sequence. EMBO J 1998, 17:5466-5476. doi:10.1093/emboj/ 17.18.5466.

79. Deibert M, Grazulis S, Sasnauskas G, Siksnys V, Huber R: Structure of the tetrameric restriction endonuclease NgoMIV in complex with cleaved DNA. Nat Struct Biol 2000, 7:792-799. doi:10.1038/79032.

80. Huai Q, Colandene JD, Topal MD, Ke H: Structure of Nael-DNA complex reveals dual-mode DNA recognition and complete dimer rearrangement. Nat Struct Biol 2001, 8:665-669. doi:10.1038/90366.

81. Campbell EA, Muzzin O, Chlenov M, Sun JL, Olson CA, Weinman O, TresterZedlitz ML, Darst SA: Structure of the bacterial RNA polymerase promoter specificity sigma subunit. Mol Cell 2002, 9:527-539.

82. Hickman AB, Ronning DR, Perez ZN, Kotin RM, Dyda F: The nuclease domain of adeno-associated virus rep coordinates replication initiation using two distinct DNA recognition interfaces. Mo/ Cell 2004, 13:403-414 
83. Pascal JM, O'Brien PJ, Tomkinson AE, Ellenberger T: Human DNA ligase I completely encircles and partially unwinds nicked DNA. Nature 2004, 432:473-478. doi:10.1038/nature03082.

84. Brissett NC, Pitcher RS, Juarez R, Picher AJ, Green AJ, Dafforn TR, Fox GC, Blanco L, Doherty AJ: Structure of a NHEJ polymerase-mediated DNA synaptic complex. Science 2007, 318:456-459. doi:10.1126/science.1145112.

85. Nandakumar J, Nair PA, Shuman S: Last stop on the road to repair: structure of E. coli DNA ligase bound to nicked DNA-adenylate. Mol Cell 2007, 26:257-271. doi:10.1016/j.molcel.2007.02.026.

86. Dürr H, Körner C, Müller M, Hickmann V, Hopfner K: X-ray structures of the Sulfolobus solfataricus SWI2/SNF2 ATPase core and its complex with DNA. Cell 2005, 121:363-373. doi:10.1016/j.cell.2005.03.026.

87. Vanamee ES, Viadiu H, Kucera R, Dorner L, Picone S, Schildkraut I, Aggarwal AK: A view of consecutive binding events from structures of tetrameric endonuclease Sfil bound to DNA. EMBO J 2005, 24:4198-4208. doi:10.1038/sj.emboj.7600880.

88. Kaus-Drobek M, Czapinska H, Sokołowska M, Tamulaitis G, Szczepanowski $\mathrm{RH}$, Urbanke C, Siksnys V, Bochtler M: Restriction endonuclease Mval is a monomer that recognizes its target sequence asymmetrically. Nucleic Acids Res 2007, 35:2035-2046. doi:10.1093/nar/gkm064.

89. Löwe J, Ellonen A, Allen MD, Atkinson C, Sherratt DJ, Grainge I: Molecular mechanism of sequence-directed DNA loading and translocation by FtsK. Mol Cell 2008, 31:498-509. doi:10.1016/j.molcel.2008.05.027.

90. Golovenko D, Manakova E, Tamulaitiene G, Grazulis S, Siksnys V: Structural mechanisms for the $5^{\prime}-$ CCWGG sequence recognition by the $\mathrm{N}$ - and Cterminal domains of EcoRll. Nucleic Acids Res 2009, 37:6613-6624. doi:10.1093/nar/gkp699.

91. Lambert AR, Sussman D, Shen B, Maunus R, Nix J, Samuelson J, Xu S, Stoddard BL: Structures of the rare-cutting restriction endonuclease Not reveal a unique metal binding fold involved in DNA binding. Structure 2008, 16:558-569. doi:10.1016/j.str.2008.01.017.

92. Georgescu RE, Kim S, Yurieva O, Kuriyan J, Kong X, O'Donnell M: Structure of a sliding clamp on DNA. Cell 2008, 132:43-54. doi:10.1016/j. cell.2007.11.045.

Cite this article as: Malhotra and Sowdhamini: Re-visiting protein-centric two-tier classification of existing DNA-protein complexes. BMC Bioinformatics 2012 13:165.

\section{Submit your next manuscript to BioMed Central and take full advantage of:}

- Convenient online submission

- Thorough peer review

- No space constraints or color figure charges

- Immediate publication on acceptance

- Inclusion in PubMed, CAS, Scopus and Google Scholar

- Research which is freely available for redistribution 